\title{
PENGARUH EKSTRAK ETANOL 70\% RIMPANG BANGLE \\ (Zingiber purpureum Roxb.) DALAM MENGHAMBAT PERTUMBUHAN Tricophyton \\ rubrum SECARA in vitro.
}

\author{
Khusnul*, Siti Rohmah Aulia, dan Lia Aulia Rahmah \\ Program Studi D-III Analis Kesehatan \\ STIKes Bakti Tunas Husada Tasikmalaya \\ *E-mail: khusnul@stikes-bth.ac.id
}

Received: 30/01/2021, Revised: 26/02/2021, Accepted: 06/07/2021, Published: 18/08/2021

\begin{abstract}
ABSTRAK
Rimpang bangle (Zingiber purpureum Roxb.) digolongkan sebagai rempah-rempah yang memiliki khasiat obat, seperti rimpangnya yang dapat dimanfaatkan sebagai bumbu dapur dan bahan pengobatan. Rimpang bangle mengandung senyawa kimia diantaranya adalah minyak atsiri, saponin, tanin, alkaloid, dan terpenoid. Zingiber purpureum Roxb. merupakan salah satu rimpang yang dipercaya memiliki khasiat untuk mengobati berbagai penyakit, salah satunya penyakit yang disebabkan oleh jamur. Penelitian ini bertujuan untuk mengetahui daya hambat ekstrak etanol 70\% rimpang bangle (Zingiber purpureum Roxb.) terhadap pertumbuhan jamur Tricophyton rubrum. Uji daya hambat ekstrak etanol 70\% rimpang bangle (Zingiber purpureum Roxb.) terhadap pertumbuhan jamur Tricophyton rubrum dilakukan dengan menggunakan Metode Kirby-Bauer. Hasil penelitian yang diperoleh, ekstrak etanol 70\% rimpang bangle (Zingiber purpureum Roxb.) berpengaruh dalam menghambat pertumbuhan jamur Tricophyton rubrum dari konsentrasi $10 \%$ rata-rata zona hambat yang terbentuk sebesar 5,66 mm, 20\% sebesar $10 \mathrm{~mm} ; 30 \%$ sebesar $12 \mathrm{~mm}$; $40 \%$ sebesar 13,66 mm; $50 \%$ sebesar 16,33 mm; $60 \%$ sebesar 17,66 mm; 70\% sebesar 20,66 mm; $80 \%$ sebesar 24,23 mm; $90 \%$ sebesar 28,33 mm; dan 100\% sebesar 43,33 mm. Berdasarkan hasil penelitian yang diperoleh tersebut menunjukkan bahwa rimpang bangle (Zingiber purpureum Roxb.) berpotensi sebagai antijamur.
\end{abstract}

Kata kunci : Ekstrak etanol, Tricophyton rubrum, Zingiber purpureum Roxb.

\begin{abstract}
Rhizome bangle (Zingiber purpureum Roxb.) is classified as a spice that has medicinal properties, such as its rhizome which can be used as a spice and ingredients for treatment. Rhizome bangle contains chemical compounds including essential oils, saponins, tannins, alkaloids, and terpenoids. Zingiber purpureum Roxb. is a rhizome that is believed to have properties to treat various diseases, one of which is a disease caused by fungi. Tricophyton rubrum is one of the fungi that can cause skin diseases including tinea pedis, tinea corporis, tinea unguium, tinea barbae and tinea cruris. This study aims to determine the inhibition of $70 \%$ ethanol extract of bangle rhizome (Zingiber purpureum Roxb.) on the growth of Tricophyton rubrum fungi. The inhibition test of $70 \%$ ethanol extract of bangle rhizome (Zingiber purpureum Roxb.) on the growth of Tricophyton rubrum mushrooms was carried out using the Kirby-Bauer Method. The results
\end{abstract}


obtained, $70 \%$ ethanol extract of bangle rhizome (Zingiber purpureum Roxb.) has an effect on inhibiting the growth of the fungus Tricophyton rubrum., from a concentration of $10 \%$ the average inhibition zone formed by $5,66 \mathrm{~mm}, 20 \%$ by $10 \mathrm{~mm} ; 30 \%$ by $12 \mathrm{~mm} ; 40 \%$ of $13.66 \mathrm{~mm} ; 50 \%$ of $16,33 \mathrm{~mm} ; 60 \%$ of $17,66 \mathrm{~mm} ; 70 \%$ of $20,66 \mathrm{~mm} ; 80 \%$ of $24,23 \mathrm{~mm} ; 90 \%$ of $28,33 \mathrm{~mm}$; and $100 \%$ by 43,33 mm. Based on the results obtained, it shows that the rhizome of bangle (Zingiber purpureum Roxb.) has the potential as antifungal.

Keywords: Ethanol extract, Tricophyton rubrum, Zingiber purpureum Roxb.

\section{PENDAHULUAN}

Indonesia memiliki iklim yang tropis, pada musim kemarau berkepanjangan merupakan kondisi yang sangat baik bagi perkembangan bakteri, virus, jamur dan parasit karena kelembaban udaranya yang cukup tinggi.

Salah satu mikroorganisme yang merugikan yaitu jamur akan tumbuh dibagian tubuh tertentu pada manusia yang akan menimbulkan penyakit, salah satunya adalah tinea pedis. Penyakit ini merupakan salah satu dermatofitosis yang sering terjadi menginfeksi daerah tumit, sela-sela jari dan telapak kaki yang salah satunya di akibatkan karena jamur Trichophyton rubrum (Irianto, 2014).

Trichophyton rubrum adalah salah satu spesies jamur yang menyebabkan dermatofitosis, yang menyerang jaringan mengandung zat tanduk (keratin) pada kuku, rambut dan stratum korneum pada epidermis. Jamur Trichophyton rubrum merupakan jamur penyebab infeksi di Indonesia (Volk dan Wheeler, 1993).
Masyarakat cenderung lebih memilih cara yang instan untuk mengobati penyakit. Selain pengobatan secara medis, penggunaan tanaman sebagai obat sudah dilakukan sejak dahulu kala di Indonesia. Salah satu tanaman yang dimanfaatkan masyarakat sebagai obat yaitu bangle (Zingiber purpureum Roxb.) karena berpotensi memiliki komponen aktif yang dapat digunakan untuk pengobatan yang bersifat antibakteri dan antifungi.

Antijamur adalah suatu bahan yang dapat mengganggu pertumbuhan dan metabolisme mikroorganisme jamur. Bahan antijamur yang ideal harus memenuhi syaratsyarat seperti: obat harus bersifat fungisida adalah yang dapat membunuh jamur dan fungistatik bersifat menghambat pertumbuhan jamur (Setiabudy dan Bahry, 2011).

Beberapa penelitian yang berkaitan dengan uji daya hambat ekstrak etanol rimpang bangle terhadap jamu patogen belum banyak diteliti, terdapat penelitian yang terkait yaitu yang dilakukan oleh Astuti (2013) berjudul "Uji Aktivitas Antimikroba Ekstrak Etanol 70\% Rimpang Bangle 
(Zingiber purpureum Roxb.) Terhadap Bakteri Staphylococcus aureus dan Jamur Microsporum canis" menunjukkan bahwa ekstrak etanol $70 \%$ rimpang bangle (Zingiber purpureum Roxb.) mengandung senyawa aktif golongan saponin, flavonoid, steroid dan triterpenoid dan mempunyai aktivitas antimikroba. Penelitian lainya yang dilakukan oleh Mozer H, (2015) "Efek Antifungi Ekstrak Etanol 96\% Kulit Batang Kayu Jawa (Lannea coromandelica) Terhadap Aspergillus niger, Candida albicans, dan Tricophyton rubrum".

Berdasarkan masalah pada latar belakang tersebut, maka penelitian tentang "Uji Daya Hambat Ekstrak Etanol 70\% Rimpang Bangle (Zingiber purpureum Roxb.) Terhadap Pertumbuhan Jamur Tricophyton rubrum Secara in vitro", dapat dijadikan referensi baru sebagai informasi jenis rimpang yang dapat menghambat penyakit infeksi yang disebabkan jamur Tricophyton rubrum, karena penelitian mengenai uji daya hambat ekstrak etanol $70 \%$ rimpang bangle (Zingiber purpureum Roxb.) terhadap pertumbuhan Tricophyton rubrum belum pernah dilakukan sebelumnya.

\section{METODE PENELITIAN}

Metode yang digunakan pada penelitian uji daya hambat ekstrak etanol $70 \%$ rimpang bangle (Zingiber purpureum Roxb..) terhadap pertumbuhan jamur Tricophyton rubrum yaitu bersifat eksperimen, menggunakan metode KirbyBauer dengan sampel yang diambil dari biakan murni yang telah dikultur pada media Sabouraud Dextrose Agar (SDA) dan diberi ekstrak etanol rimpang bangle kemudian diinkubasi pada suhu $25-30^{\circ} \mathrm{C}$ selama 4 hari.

\section{Alat dan Bahan}

Alat yang digunakan yaitu autoklaf (Portable M300), mikroskop cahaya (olympus CX23), evaporator (IKA RV 10), dry sterilisator (Corona ZTP8A-7 (Sinar IR), inkubator (Memmert UNB 4000, neraca analitik (Excellent Analytical Balance AB HZK-2104, oven (T100-200), batang pengaduk, benang kasur, cawan petri, gelas kimia, erlenmeyer, gelas ukur, labu spirtus, ose bulat, hot plate, mikropipet, tip, spatula, tabung reaksi, kain kasa, kertas payung, Bahan yang digunakan yaitu Sabouraud Dextrose Agar (oxoid), $\mathrm{NaCl}$ Fisiologis, $\mathrm{BaCl}_{2} 1 \%, \mathrm{H}_{2} \mathrm{SO}_{4} 1 \%$, ketokonazol 2\%, ekstrak etanol rimpang bangle, etanol 96\%, biakan jamur Trichophyton rubrum, dan aquadest steril. 


\section{Jalannya Penelitian}

1. Pembuatan Ekstrak Etanol $70 \%$ Rimpang Bangle (Zingiber purpureum Roxb.) Dengan Metode Maserasi Menurut Depkes, (2000)

Pembuatan ektrak etanol rimpang bangle dengan menimbang simplisia rimpang bangle yang telah dihaluskan sebanyak 160 gram, memasukkanya kedalam gelas kimia. Kemudian menambahkan pelarut etanol $70 \%$ sebanyak $800 \mathrm{~mL}$ (perbandingan 1:5) (Rahmi, 2016), larutan tersebut diremdam selama $2 \times 24$ jam sambil sesekali diaduk. Kemudian menguapkan filtrat menggunakan alat rotary evaporator dengan suhu $50-65^{\circ} \mathrm{C}$ sehingga pelarutnya menguap. Filtrat diuapkan kan kembali dalam penangas air dengan suhu $50-65^{\circ} \mathrm{C}$ sehingga diperoleh ekstrak kental.

2. Uji daya hambat ekstrak etanol $70 \%$ rimpang bangle (Zingiber purpureum Roxb.)

a. Suspensi jamur Tricophytonrubrum sebanyak $100 \mu \mathrm{l}$ dengan kekeruhan 0,5 Mc Farland dituangkan ke dalam media SDA dengan mikropipet dan meratakannya menggunakan batang L.

b. Kertas cakram disiapkan pada botol vial dan direndami pelarut (aquadest steril) yang telah ditambahkan ekstrak etanol rimpang bangle dengan variasi konsentrasi 10\%, 20\%, 30\%, 40\%, 50\%, $60 \%, 70 \%, 80 \%$, $90 \%$, dan $100 \%$ serta dibuat kontrol positif (ketokonazol 2\%) dan kontrol negatif (aquadest steril).

c. Kertas cakram (Blank disk) yang telah direndam dengan ekstrak, kontrol positif dan negatif diambil dan ditempelkan pada permukaan media SDA pada cawan petri.

d. Media SDA diinkubasi pada suhu kamar $\left(25-30^{\circ} \mathrm{C}\right)$ selama 4 hari, adanya zona hambat disekitar kertas cakram diamati dan zona hambat yang terbentuk diukur. (Cappucino,1987).

e. Variabel bebas yang digunakan adalah variasi konsentrasi ekstrak 10\%, 20\%, $30 \%, 40 \%, 50 \%, 60 \%, 70 \%, 80 \%, 90 \%$, dan $100 \%$. Variabel terikat yang digunakan adalah zona hambat ekstrak etanol $70 \%$ rimpang bangle (Zingiber purpureum Roxb..) terhadap pertumbuhan Tricophyton rubrum.

3. Uji Fitokimia

a. Alkaloid

Ekstrak di dalam tabung reaksi dilarutkan dengan asam klorida dan disaring. Filtrat ditambahkan 2-3 tetes pereaksi Dragendorff dengan hasil positif terbentuk endapan merah. Jika ditambahkan dengan 23 tetes pereaksi Mayer hasil positif terbentuk endapan kuning (Tiwari et al., 2011) 
b. Saponin

Ekstrak $\quad 0,5$ gram ditambahkan dengan $2 \mathrm{~mL}$ air. Kemudian dikocok, jika hasilnya terdapat busa menunjukkan adanya saponin (Tiwari et al., 2011)

c. Tanin

Larutan ekstrak sebanyak $0,5 \mathrm{~mL}$, ditambahkan $1 \mathrm{~mL}$ aquades dan 1-2 tetes larutan Ferri klorida hasil positif warna biru (Sakhti et al., 2011)

d. Flavonoid

Ekstrak ditambahkan 1,5 mL larutan metanol 50\%. Kemudian ditambahkan 5-6 tetes asam klorida pekat, hasil positif terbentuk warna merah menunjukkan adanya flavonoid, jika terbentuk warna orange menunjukkan adanya flavon (Sakhti et al., 2011)

e. Glikosida

Ekstrak ditambahkan dengan asam asetat glasial dan 1-2 tetes Ferri klorida serta asam sulfat pekat, hasil positif pembentukan dua lapisan dengan warna coklat kemerahan lapisan tengah dan warna hijau kebiruan lapisan atas (Sakthi et al., 2011).

f. Terpenoid dan Steroid

Ekstrak ditambahkan 0,5 mL asam asetat anhidrat dan 0,5 mL kloroform serta 12 tetes asam sulfat pekat. Hasil positif warna ungu kemerahan berarti positif terpenoid.
Apabila terbentuk warna hijau kebiruan berarti positif steroid (Sakthi et al.,2011).

\section{Analisis Data}

Hasil diameter daya hambat dianalisis menggunakan uji parametrik dengan metode One way anova (analisis varian satu arah) dengan taraf kepercayaan $95 \%$ atau $\alpha=0,05$, apabila hasil uji tersebut menunjukkan hasil signifikan dilanjutkan dengan uji Duncan atau DMRT.

\section{HASIL DAN PEMBAHASAN}

Penelitian uji daya hambat ekstrak etanol $70 \%$ rimpang bangle (Zingiber purpureum Roxb.) terhadap pertumbuhan jamur Tricophyton rubrum dilaksanakan di Laboratorium Parasitologi STIKes Bakti Tunas Husada Tasikmalaya. Berdasarkan hasil analisis varian menunjukkan bahwa beberapa konsentrasi ekstrak etanol rimpang bangle (Zingiber purpureum Roxb.) terhadap pertumbuhan jamur Tricophyton rubrum. Hal tersebut menunjukkan bahwa ekstrak etanol rimpang bangle berpengaruh terhadap pertumbuhan jamur Tricophyton rubrum. Hasil ini dilanjutkan dengan uji duncan dengan hasil seperti pada Tabel 1.

Hasil analisis yang tertera pada Tabel 1 dibawah, menunjukkan bahwa kemampuan dari setiap konsentrasi ekstrak bunga cengkeh terhadap pertumbuhan T.rubrum 
menghasilkan zona hambat yang berbeda nyata, namun terdapat beberapa konsentrasi yang kemampuan daya hambatnya tidak berbeda nyata yaitu antara konsentrasi $50 \%$ dengan 60\% dengan kemampuan rerata zona hambat masing-masing 16,33 dan 17,66 mm.
Kemampuan daya hambat konsentrasi 100\% terdapat perbedaan yang bermakna dengan hasil dari kontrol positif (ketokonazol 2\%) yaitu dengan rerata zona hambat masingmasing 43,33 dan $33 \mathrm{~mm}$.

Tabel 1. Zona hambat ekstrak etanol 70\% rimpang bangle (Zingiber purpureum Roxb.) terhadap pertumbuhan jamur Tricophyton rubrum

\begin{tabular}{|c|c|c|}
\hline $\begin{array}{c}\text { Kons. } \\
\text { Ekstrak }\end{array}$ & $\begin{array}{c}\text { Rerata } \\
\text { diameter Daya } \\
\text { Hambat (mm) }\end{array}$ & $\begin{array}{c}\text { Repson } \\
\text { Daya } \\
\text { Hambat }\end{array}$ \\
\hline $10 \%$ & $5,66 \mathrm{a} \pm 0,577$ & Lemah \\
\hline $20 \%$ & $10 \mathrm{~b} \pm 1$ & Sedang \\
\hline $30 \%$ & $12 \mathrm{c} \pm 1$ & Sedang \\
\hline $40 \%$ & $13,66 \mathrm{~d} \pm 0,577$ & Sedang \\
\hline $50 \%$ & $16,33 \mathrm{e} \pm 0,577$ & Kuat \\
\hline $60 \%$ & $17,66 \mathrm{e} \pm 0,577$ & Kuat \\
\hline $70 \%$ & $20,66 \mathrm{f} \pm 1,154$ & Sangat Kuat \\
\hline $80 \%$ & $24,33 \mathrm{~g} \pm 0,577$ & Sangat Kuat \\
\hline $90 \%$ & $28,33 \mathrm{~h} \pm 0,577$ & Sangat Kuat \\
\hline $100 \%$ & $43,33 \mathrm{j} \pm 1,527$ & Sangat Kuat \\
\hline Kontrol (+) & $33 \mathrm{i} \pm 1$ & Sangat Kuat \\
\hline Kontrol (-) & - & \\
\hline
\end{tabular}

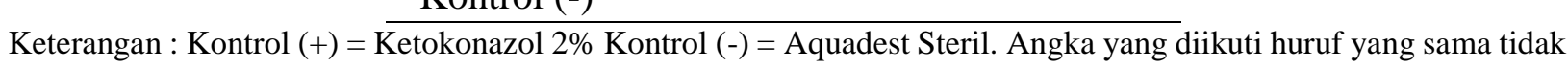
berbeda pada tingkat kesalahan $5 \%$.
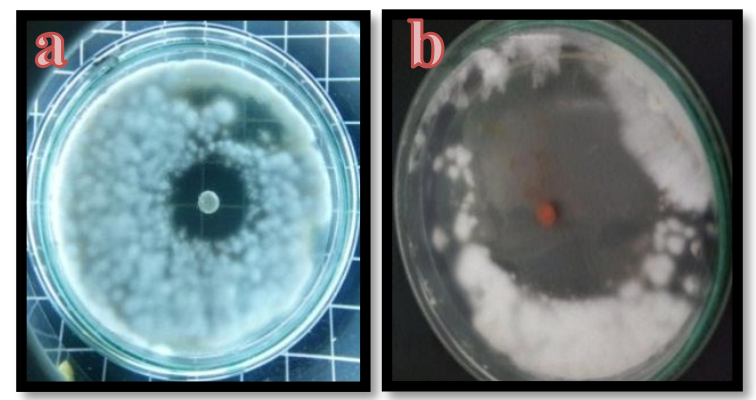

Gambar 1. Morfologi makroskopis jamur Tricophyton rubrum, (a. Kontrol positif); (b. Diameter zona hambat konsentrasi $100 \%$.

Gambar 1 menunjukkan bahwa pertumbuhan jamur Tricophyton rubrum dapat dihambat dengan baik oleh ekstrak 146 rimpang bangle yang dilihat dari diameter zona hambat melebihi kontrol positif. Sedangkan untuk kontrol negatif (aquadest 
steril), hasil yang diperoleh pada kontrol aquadest steril tidak terdapat zona hambat yang terbentuk.

Terbentuknya zona hambat tersebut tidak terlepas dari senyawa aktif yang terkandung pada rimpang bangle. Uji senyawa aktif dapat dilakukan dengan cara uji fitokimia dimana hasil positif nya dapat dilihat dari perubahan ekstrak rimpang bangle pada saat penambahan pelarut tertentu.

Uji penapisan fitokimia pada rimpang bangle, telah dilakukan dimana hasilnya positif alkaloida yang dapat menghambat esterase dan juga DNA dan RNA polymerase serta menghambat respirasi sel (Olivia, 2004) , saponin yang mengakibatkan sel mikroba lisis dengan mengganggu stabilitas membran sel (Wulansari, 2009), flavonoid yang menyebabkan gangguan dalam pembentukan sel sehingga merubah komposisi komponen protein (Wahyuningtyas, 2008) dan terpenoid yang menimbulkan kerusakankerusakan pada organel-organel sel sehingga dapat menghambat terjadinya pertumbuhan jamur pathogen (Ismaini, 2011). Hasil uji fitokimia ekstrak rimpang bangle dapat dilihat pada Tabel 2 .

Tabel 2. Hasil skrining uji fitokimia ekstrak rimpang bangle (Zingiber purpureum Roxb..)

\begin{tabular}{cccl}
\hline No. & $\begin{array}{c}\text { Uji } \\
\text { Fitokimia }\end{array}$ & $\begin{array}{c}\text { Hasil } \\
\text { Pengujian }\end{array}$ & \multicolumn{1}{c}{ Keterangan } \\
\hline 1. & Alkaloida & + & $\begin{array}{l}\text { Terbentuknya } \\
\text { endapan kuning }\end{array}$ \\
2. & Saponin & + & $\begin{array}{l}\text { Terbentuknya } \\
\text { buih }\end{array}$ \\
3. & Tanin & - & $\begin{array}{l}\text { Terbentuknya } \\
\text { warna hitam dan } \\
\text { endapan kuning }\end{array}$ \\
4. & Flavonoid & + & $\begin{array}{l}\text { Terbentuknya } \\
\text { warna orange }\end{array}$ \\
5. & Glikosida & - & $\begin{array}{l}\text { Terbentuknya } \\
\text { warna hitam } \\
\text { pekat dan tidak } \\
\text { terbentuk dua } \\
\text { lapisan } \\
\text { Terbentuknya } \\
\text { warna ungu } \\
\text { kemerahan }\end{array}$ \\
\hline
\end{tabular}

Beberapa penelitian yang lain belum banyak meneliti dengan objek yang sama dengan penelitian ini, namun terdapat penelitian terhadap pertumbuhan bakteri yaitu oleh Astuti (2013) berjudul yaitu menguji Ekstrak Etanol 70\% Rimpang 
Pharmacoscript Volume 4 No. 2 Agustus 2021

Bangle (Zingiber purpureum Roxb.) Terhadap Bakteri Staphylococcus aureus dan Jamur Microsporum canis hasil penelitiannya menunjukkan bahwa ekstrak etanol $70 \%$ rimpang bangle (Zingiber purpureum Roxb.) mengandung senyawa aktif golongan saponin, flavonoid, steroid dan triterpenoid dan mempunyai aktivitas antimikroba. Hasil penelitiannya, terdapat zona hambat terhadap bakteri Staphylococcus aureus dengan konsentrasi $0,4 \% ; 0,2 \%$; dan $0,1 \%$. Sedangkan pada jamur Microsporum canis terdapat zona hambat pada konsentrasi $0,4 \% ; 0,2 \% ; 0,1 \%$; $0,05 \% ; 0,025 \% ; 0,0125 \%$. Selain itu, penelitian yang dilakukan oleh Citra Dewi dkk (2019) tentang Daya Hambat Ekstrak Rimpang Bangle (Zingiber purpureum Roxb.) terhadap Pertumbuhan Bakteri Staphylococcus aureus dengan hasil Ekstrak rimpang bangle pada konsentrasi $25 \%, 50 \%$, $75 \%$, dan $100 \%$ memiliki daya hambat yang kuat terhadap pertumbuhan bakteri Staphylococcus aureus. Hasil penelitian lain yang berhubungan yaitu oleh Marliani (2012), pengujian minyak atsiri rimpang bangle terhadap pertumbuhan Staphylococcus aureus dan Eschericia coli menunjukkan nilai Konsentrasi Hambat Minimum (KHM) sebesar 3,125\% untuk kedua bakteri tersebut. Penelitian yang dilakukan oleh Pithayanukul (2006) menunjukkan minyak atsiri rimpang bangle mampu menghasilkan konsentrasi bunuh minimum (KBM) pada bakteri yang ditentukan dengan metode makrodilusi cair dengan nilai berkisar antara 0,62 hingga 2,5 vol \% sedangkan konsentrasi fungisida minimum berkisar antara 0,31 hingga 1,25\% vol. Penelitian yang dilakukan oleh Kamazeri dkk (2011) minyak esensial Zingeber cassumunar menunjukkan aktivitas antimikroba yang lemah atau tidak ada dalam menghambat pertumbuhan Bacillus cereus, E. coli, C. albicans dan C. neoforman. Al fahdawi and Marwan T J (2020) melaporkan hasil Skrining filokimia ekstrak Zingiber officinale yaitu terdapat senyawa Saponin, Terpen dan Antrakuinon. Aktivitas antimikroba belum adanya perbedaan yang cukup bermakna dalam menghambat pertumbuhan bakteri serta jamur, sedangkan konsentrasi bubuk Ginger memiliki dampak yang cukup besar pada zona hambat bakteri juga jamur. Penelitian yang dilakukan oleh Gayathri et al (2021) yaitu menguji aktivitas antimikroba pada E. coli, Staphylococcus aureus, K. pneumoniae dan Pseudomonas aeroginosa dari rimpang segar dan kering Zona hambat maksimum pada $K$. pneumoniae sebesar $25 \mathrm{~mm}$ diikuti oleh Staphylococcus aureus sebesar $24 \mathrm{~mm}$, 
Pseudomonas aeroginosa dan E. coli masing-masing menunjukkan $22 \mathrm{~mm}$. Selain itu menguji Aktivitas antijamur pada Aspergillus flavus, A. terreus, Penicillum $\mathrm{sp}$ dan Fusarium sp,Zona hambat maksimum yaitu pada konsentrasi 100 g sampel segar terhadap Fusarium sp sebesar 14 mm, diikuti oleh A. flavus sebesar $12 \mathrm{~mm}$, A. terreus sebesar $10 \mathrm{~mm}$ dan Penicillum sp sebesar 10 $\mathrm{mm}$.

\section{KESIMPULAN}

Ekstrak Etanol 70\% Rimpang Bangle (Zingiber purpureum Roxb.) berpengaruh dalam menghambat pertumbuhan jamur Tricophyton rubrum, yaitu pada konsentrasi $10 \%, 20 \%, 30 \%, 40 \%, 50 \%, 60 \%, 70 \%, 80 \%$, $90 \%$ dan $100 \%$. Semakin tinggi konsentrasi ekstrak semakin besar juga zona hambat yang dihasilkan.

\section{DAFTAR PUSTAKA}

ALFahdawi Shakir M. S. and Marwan Talib Joudah. (2020). Study On Antibacterial And Antifungal Activity Of Ginger (Zingiber officinale) On Selected Pathogenic Microorganism. Biochem. Cell. Arch. 20 (2), pp. 4629-4633.

Astuti, T. B. (2013). Uji AKtivitas Antimikroba Ekstrak Etanol 70\% Rimpang Bangle (Zingiber purpureum
Roxb..) terhadap Bakteri Staphylococcus aureus ATCC 25925 dan Jamur Microsporum canis secara in vitro. Skripsi. Fakultas Kedokteran dan Ilmu Kesehatan Program Studi Farmasi. UIN Syarif Hidayatullah Jakarta.

Cappucino, JG.\& Sherman. (1987). N, Microbiology : A Laboratory Manual, The Benjamn/Cummings Publishin Company: Icn Clifornia

Citradewi A, Sumarya, I M. , Juliasih, N. K. A. (2019). Daya Hambat Ekstrak Rimpang Bangle (Zingiber purpureum Roxb...) Terhadap Pertumbuhan Bakteri Staphylococcus aureus. Widya Biologi. 1 (1): 45-53.

Gayathri G, S. Gomathi1, V. Ambikapathy and A. Panneerselvam. (2021). Comparative Study Of Antimicrobial Activity On Fresh And Dried Zingiber officinale rosc. Asian Journal of Advances in Medical Science. 2(4): 1623.

Depkes RI. (2000). Parameter Standar Umum Ekstrak Tumbuhan Obat. Direktorat Jendral Pengawasan Obat dan Makanan: Jakarta.

Irianto. (2014). Bakteriologi, Mikologi, dan Virologi Panduan Medis dan Klinis. ALFABETA: Bandung. 
Ismaini, L. (2011). Aktivitas Antifungi Ekstrak (Centella asiatica (L.)) Urban Terhadap FungiPatogen pada Daun Anggrek (Bulbophyllum flavidiflorum Carr). Jurnal Penelitian Sains. 14 (1).

Kamazeri Tg Siti Amirah Tg, Othman Abd Samah, Muhammad Taher, Deny Susanti, Haitham Qaralleh. Antimicrobial activity and essential oils of Curcuma aeruginosa, Curcuma mangga, and Zingiber cassumunar from Malaysia. Asian Pacific Journal of Tropical Medicine.

Marliani L. (2012). Aktivitas Antibakteri dan Telaah Senyawa Komponen Minyak Atsiri Rimpang Bangle (Zingiber cassumunar Roxb..). Prosiding Seminar Nasional Penelitian dan PKM : Sains, Teknologi dan Kesehatan. 3 (1).

Mozer H. (2015). Uji Antifitas Antifungi Ekstrak Etanol 96\% Kulit Batang Kayu Jawa (Lannea coromandelica) terhadap Aspergillus niger, Candida albicans dan Trichophyton rubrum. [Skripsi]. Fakultas Kedokteran dan Ilmu Kesehatan Program Studi Farmasi. UIN Syarif Hidayatullah Jakarta.

Olivia, F. , Alam, S., \& Hadibroto, I. (2004).

Seluk Beluk Food Suplemen. Jakarta: Gramedia. pp. 49
Rahmi A, Erfan Roebiakto, Leka Lutpiatina. (2016). Potensi Ekstrak Rimpang Kencur (Kaemperia galanga.L) Menghambat Pertumbuhan Candida albican. Medical Laboratory Technology Journal. 2 (2) : 70-76.

Sakhti et al. (2011). Pharmacological Screening of Daturametel. International journal of pharmaceutical science and health care.

Setiabudy, R. \& Bahry, B. (2011). Obat Jamur. In: S. G. Gunawa, R. Setiabudy, Nafriadi \& Elysabeth, eds Farmakologi dan Terapi ed 5, Badan Penerbit FKUI: Jakarta.pp 581

Tiwari et al. (2011). Department of Pharmaceutical Sciences. Dalam Lovely School of Pharmaceutical. Phagwara: Punjab.

Pithayanukul P, J. Tubprasert, M. WuthiUdomlert. (2006). In Vitro antimicrobial activity of Zingiber cassumunar (Plai) oil and a 5\% Plai oil gel. Phytotherapy Research. 21 (2).

Volk, W.A and M.F. Weeler. (1993). Microbiology Laboratory : Fundamentals And Apllications. 2 $2^{\text {nd }}$ Edition. Pearson Education Inc: New Jersey. USA. 
Khusnul et al.;Pengaruh Ekstrak Etanol 70\% Rimpang.....Pharmacoscript Volume 4 No. 2, Agustus 2021

Wahyuningtyas, Endang. (2008). Pengaruh Ekstrak Graptophyllum pictum Terhadap Pertumbuhan Candida albicans Pada Plat Gigi Tiruan Resin Akrilik. Indonesian Journal of Dentistry. Vol 15 (3): 188.

Wulansari, L., (2009). Kajian ekstrak pandan wangi (Pandanus amryllifolius Roxb..) sebagai repellent bagi nyamuk Aedes aegypti, Fakultas Biologi. Universitas Jendral Soedirman, Purwokerto 